\title{
Problemy konstrukcyjno-konserwatorskie w obiektach zabytkowych - wybrane przykłady z terenu Lublina i Lubelszczyzny
}

\author{
Halina Landecka \\ e-mail: h.landecka@pollub.pl \\ Wydziat Budownictwa i Architektury, Katedra Architektury, \\ Urbanistyki i Planowania Przestrzennego, Politechnika Lubelska \\ Faculty of Civil Engineering and Architecture, Department of Architecture, \\ Urban and Spatial Planning, Lublin University of Technology
}

\begin{abstract}
Streszczenie: Remont i adaptacja zabytku architektury do nowych funkcji wymaga współdziałania specjalistów z zakresu konserwacji, architektury i konstrukcji. Istotne jest rzetelne rozpoznanie historii budynku, stanu zachowania zabytkowej struktury, przewidywanego sposobu dalszego użytkowania. Przy opracowaniu oceny stanu zabytku oraz projektowaniu rozwiązań powinny brać udział osoby posiadające nie tylko właściwe wykształcenie zawodowe, ale także doświadczenie w pracy przy zabytkach.

Tylko tacy specjaliści potrafią podjąć właściwe decyzje dotyczące remontu, zabezpieczenia czy - w skrajnych przypadkach rozbiórki budynku. Wskazuje na to wiele przykładów postępowania z zabytkami architektury z terenu Lublina i Lubelszczyzny.
\end{abstract}

Słowa kluczowe: adaptacja zabytku, zabezpieczenie, konserwacja

\section{Wstęp}

Zabytek architektury - tak jak każdy inny obiekt budowlany - powinien spełniać kryteria bezpieczeństwa według warunków technicznych jakie określa prawo budowlane. Wiele historycznych budynków adaptowanych do nowych funkcji użytkowych poddawanych jest zmianie obciążeń, nadbudowie lub przebudowie. Część z nich ze względu na liczne wcześniejsze przekształcenia, czasem także wieloletni brak użytkownika i związane z tym uszkodzenia spowodowane brakiem remontów znajduje się w stanie niezadawalającym, a nawet awaryjnym.

Punktem wyjścia przy projektowaniu i prowadzeniu remontu zabytku jest określenie jego stanu technicznego, w tym: rodzaju ustroju, wytrzymałości materiałów, zakresu dotychczasowych ingerencji (wzmocnień, napraw, przebudów, rekonstrukcji). Zadaniem konstruktora jest zabezpieczenie obiektu zarówno w trakcie badań wstępnych, jak i w toku robót budowlanych. ${ }^{1}$ Diagnozę stanu konstrukcji budynku, identyfikację zagrożeń, wnioski i zalecenia opracować powinna osoba posiadająca stosowne uprawnienia budowlane do pełnienia samodzielnych funkcji technicznych. Jednak w przypadku obiektu historycznego obok uprawnień i umiejętności inżynierskiej oceny niezwykle istotne jest doświadczenie w pracy przy zabytkach i wiedza specjalistyczna dotycząca ich specyfiki. Niezbędne jest uwzględnienie uwarunkowań wynikających z aktualnego stanu technicznego, ale także wymogów konserwatorskich, zamierzonych zmian funkcjonalnych i aktualnych wymogów normatywnych. ${ }^{2}$

Tematyka starych technik budowlanych stosowanych w zabytkowych budynkach: konstrukcji zabytkowych stropów, sklepień, fundamentów, więźb drewnianych, tradycyjnych materiałów wykończeniowych, detali

1 T. Seruga, M. Płachecki, S. Seruga, Problemy konstrukcyjnego przystosowania obiektu przemysłowego do nowej funkcji, Budownictwo. Czasopismo Techniczne Politechniki Krakowskiej, wyd. PK 2-B/2009, zeszyt 9 rok 106, s. 321-324

2 P.Kuleta, M.Pikos, G.Słowek ,Problemy konstrukcyjne remontowanego budynku zabytkowego. Wiadomości Konserwatorskie Nr 26/2009 s. 641 
architektonicznych itd. podejmowana jest w programach nauczania niewielu uczelni technicznych. Dlatego też inżynierowie bez doświadczenia praktycznego w pracy przy zabytkach często z trudem radzą sobie z problemami konserwatorskimi na budowie.

Jak szkodliwy może być brak doświadczenia niech świadczy przykład opinii biegłego sądowego - inżyniera budowlanego, który zajął stanowisko w sprawie podziału własności zabytkowej kamienicy przy Rynku 9 na Starym Mieście w Lublinie. Bez zapoznania się z historią budynku, bez uwzględnienia opracowanej rok wcześniej ekspertyzy stanu technicznego wraz z projektem najpilniejszych robót zabezpieczających, biegły wyraził pogląd, że "wszystkie wiekowe zabytkowe budowle sa gruntownie remontowane-odbudowywane od podstaw"(?). W dalszej ocenie stwierdził konieczność "wymiany ścian piwnic i ścian fundamentowych na żelbetowe wodoszczelne", co poprawi znacząco stan przyziemia, a co ważne "takie podejście przyniesie również korzyści z towarzyszących działaniom badań archeologicznych". Bez wiedzy na temat wystroju wnętrz, wartości starych elementów konstrukcyjnych za niezbędne uznał skucie wszystkich tynków wewnętrznych i zewnętrznych, a także rozbiórkę i wymianę stropów i więźby drewnianej.

Kamienica przy Rynku 9 należy do wyjątkowo ważnych, reprezentacyjnych obiektów Starego Miasta w Lublinie, posiada zabytkową XVI w. strukturę murów i wystroju. W trakcie badań architektonicznych prowadzonych w ostatnich latach odsłonięte zostały we wnętrzach niezwykle ciekawe polichromie i kamienny portal w wejściu do sieni. Dlatego też konserwator odniósł się krytycznie do wniosków biegłego wskazując, że wnioski i sformułowania zawarte w opinii są nietrafione i świadczą o braku wiedzy i doświadczenia autora w ocenie zabytków.

\section{Specyfika procesu inwestycyjnego w zabytku}

Roboty budowlane w obiekcie zabytkowym różnią się od powszechnie znanych robót inwestycyjnych w nowym budownictwie. Każdy zabytek, każdy jego element konstrukcji, struktury i wystroju podlega indywidualnej ocenie, co wpływa na konieczność doboru indywidualnych rozwiązań zapewniających zachowanie istotnych wartości dokumentalnych i materialnych zabytku. ${ }^{3}$ Odpowiedzialność decyzyjna w zakresie podjęcia ustaleń rozciąga się na głównych uczestników procesu inwestycyjnego: konserwatora, projektantów (w szczególności architekta i konstruktora), wykonawcę i inwestora - właściciela zabytku.

Konserwator - odpowiedzialny jest z urzędu za ochronę i zachowanie zabytku, dążenie do maksymalnego poszanowanie najwartościowszych elementów, w tym oryginalnej struktury układu konstrukcyjnego (sklepień, stropów, murów zabytkowych, więźby dachowej itp.) a także wystroju obiektu (detali architektonicznych, zdobień, dekoracji wnętrz). Stanowisko konserwatora jest zdecydowanie zachowawcze, jednak podjęcie koniecznych działań naprawczych (wprowadzenie wzmocnień, systemów odciążeń, zabezpieczeń, wyburzeń) powinno nastąpić według wspólnego rozwiązania przyjętego przez wszystkich uczestników procesu w oparciu o wnikliwe analizy i przy zastosowaniu najnowszych, najlepszych metod technicznych.

Konstruktor podejmuje odpowiedzialność za bezpieczeństwo obiektu zarówno w trakcie procesu budowlanego, jak i docelowego użytkowania, architekt za założenia projektowe i koordynację ustaleń branżowych, wykonawca za prawidłowość realizacji projektu, właściciel za finansowanie prac budowlanych i konserwatorskich przy swojej nieruchomości oraz osiągnięcie założonego celu użytkowego.

W wyjątkowych sytuacjach zdarza się konieczność podjęcia decyzji o rozbiórce zabytku. Takie rozwiązanie ostateczne winno być poparte uzasadnionymi wnioskami z orzeczenia technicznego wykluczającymi możliwość uratowania obiektu i potwierdzającymi występujące zagrożenie życia lub mienia. Tu także wiedza i doświadczenie autora oceny w działaniach przy zabytkach są niezwykle istotne. O rozbiórce zabytku nie może przesądzać -jakkolwiek ważny - argument finansowy tj. nieopłacalność ekonomiczna remontu. Zgodnie z przepisami prawa ochrona i opieka nad zabytkami stanowi bowiem obowiązek właściciela bez względu na stan zachowania zabytku.

Należy przy tym zauważyć, że istotny jest status ochrony budynku. Obiekt może podlegać ochronie jako:

- zabytek indywidualnie wpisany do wojewódzkiego rejestru zabytków (dzieło architektoniczne),

- jako zabytek objęty ochroną w gminnej ewidencji zabytków lub

- jako element zabudowy chronionego układu urbanistycznego (ruralistycznego). 
W przypadku rozbiórki obiektu położonego w chronionym układzie urbanistycznym wymagana jest decyzja wojewódzkiego konserwatora zabytków, obiekty ewidencyjne podlegają jedynie opiniowaniu w toku postępowania prowadzonego przez organ budowlany. Rozbiórka zabytku objętego indywidualną, ścisłą ochroną prawną lub zabytku odnośnie którego konserwator uzna, że jest istotnym elementem układu urbanistycznego ujętego w rejestrze zabytków musi być poprzedzona uzyskaniem decyzji Generalnego Konserwatora Zabytków. Jeżeli uzna on argumenty merytoryczne wynikające z orzeczenia technicznego i wyda decyzję o skreśleniu obiektu z rejestru zabytków rozbiórka może być dokonana. Zabytek zostaje skreślony z rejestru jeżeli uległ zniszczeniu w stopniu powodującym utratę jego wartości historycznej, artystycznej lub naukowej. Niezwykle istotne jest w tym przypadku rzetelne orzeczenie techniczne sporządzone przez uprawnionego, doświadczonego konstruktora.

\section{Stan awaryjny zabytku - rozbiórka czy remont?}

Przykładem procedury poprzedzającej rozbiórkę zabytku może być postępowanie w sprawie skreślenia z rejestru zabytków i tym samym potwierdzenia zasadności rozbiórki zabytkowej oficyny w zespole kamienic przy ul. Archidiakońskiej 1 na Starym Mieście w Lublinie, w obszarze uznanym za Pomnik Historii.

Pierwszy wniosek o skreślenie z rejestru zabytków oficyny w związku z zamiarem jej rozbiórki złożony został w 2009 r. przez prywatną spółkę która nabyła nieruchomość. Dwukondygnacyjny, podpiwniczony budynek, powiązany z frontową kamienicą, usytuowany na skrajnej części staromiejskiego wzgórza był od dawna nieużytkowany. Jego stan określany był jako zły, brak było dachu, występowały liczne spękania murów, ugięcia stropów, zawilgocenia. Jednak Generalny Konserwator Zabytków uznał, że zły stan zachowania nie został dostatecznie dowiedziony przez oceniającego stan techniczny konstruktora, oficyna nie utraciła wartości zabytkowych, stanowi ważny element panoramy miasta i nie powinna podlegać skreśleniu z rejestru zabytków.

Spółka ponowiła wniosek w 2012 roku, dołączając nowe dowody: ekspertyzę budowlaną opracowaną przez uprawnionego konstruktora i opinię architektoniczną. Według zgodnej opinii obu ekspertów mury oficyny i fundamenty wykazywały istotną niestabilność wynikającą z nierównomiernego osiadania gruntu, a typ uszkodzeń ścian nie pozwalał na zakwalifikowanie ich do naprawy lecz do niemal całkowitej rekonstrukcji. We wnioskach wskazano, że oficyna znajduje się w awaryjnym stanie technicznym i nie istnieje techniczne uzasadnienie jej rozległego remontu, który de facto polegałby na całkowitej wymianie struktury.

Generalny Konserwator Zabytków tym razem uznał racje wnioskodawców i wydał orzeczenie o skreśleniu oficyny z rejestru stwierdzając, że "materiał dowodowy sprawy daje podstawy do uznania, że wnioskowany do skreślenia obiekt jest w tak katastrofalnym stanie techniczny, iż konieczny remont budynku wiązałby się z całkowitą wymianą oryginalnej substancji historycznej oraz rekonstrukcją formy. Tym samym zrekonstruowany budynek byłby jedynie imitacją zabytku".

Oficynę ze względów bezpieczeństwa rozebrano, w jej miejscu zaprojektowany został analogiczny budynek - powtarzający formę w nowej aranżacji architektonicznej.

Innym przykładem jest rozbiórka tzw. „Dworku modrzewiowego” w Kraśniku, nabytego w roku 2006 przez osobę prywatną, która od razu po przejęciu obiektu wystąpiła o dokonanie jego skreślenia z rejestru zabytków. Generalny Konserwator Zabytków wydał decyzję odmowną, uznając, że zabytkowy, drewniany dworek - dawny szpital przy kościele św. Ducha - nie jest w stanie zagrożenia i wymaga podjęcia pilnych prac remontowych. Właścicielka obiektu, przymuszana interwencjami urzędu konserwatorskiego wykonała doraźne zabezpieczenia i zleciła opracowanie projektu uzyskując w 2013 roku pozwolenie budowlane na realizację remontu. Niestety, przez kolejne dwa lata prace nie zostały podjęte, a stan dworku uległ tak znacznemu pogorszeniu, że organ budowlany nakazał zabezpieczenie terenu i wygrodzenie obiektu. W tej sytuacji, ze względów konserwatorskich uznano, że należy niezwłocznie zdemontować zachowane elementy drewnianej konstrukcji i detali snycerskich, starannie je zinwentaryzować, złożyć i zabezpieczyć do ponownego wykorzystania. Ta nietypowa zgoda na rozbiórkę była jedynym ratunkiem dla zabytkowej substancji. Rekonstrukcja z wykorzystaniem oryginalnych elementów nie jest w przypadku drewnianych zabytków wyjątkowa.

Najtrudniejsze decyzje konserwatorskie i budowlane dotyczą obiektów zabytkowych, których właściciele zapewniają o woli przeprowadzenia remontu lecz latami nie podejmują docelowych robót budowlanych, a jedynie działania doraźne. Nie przynoszą efektu przymuszenia administracyjne - nakazy, grzywny nakładane przez urząd konserwatorski, interwencje nadzoru budowlanego. Stan zabytku pogarsza się stopniowo i grozi 


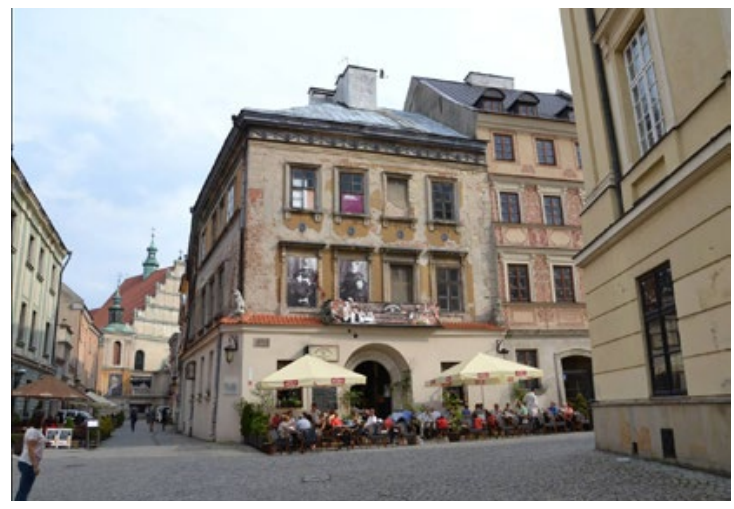

Ryc. 1. Kamienica przy Rynku 9 w Lublinie. Fot. Ze zbiorów WKZ Lublin.

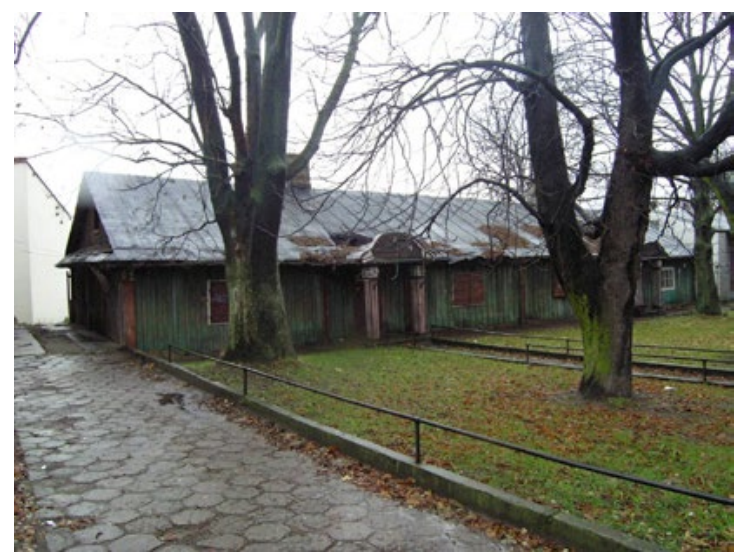

Ryc. 3. Dworek Modrzewiowy w Kraśniku (d. szpital przy kościele św. Ducha) - stan z 2006 r. Fot. ze zbiorów WKZ Lublin

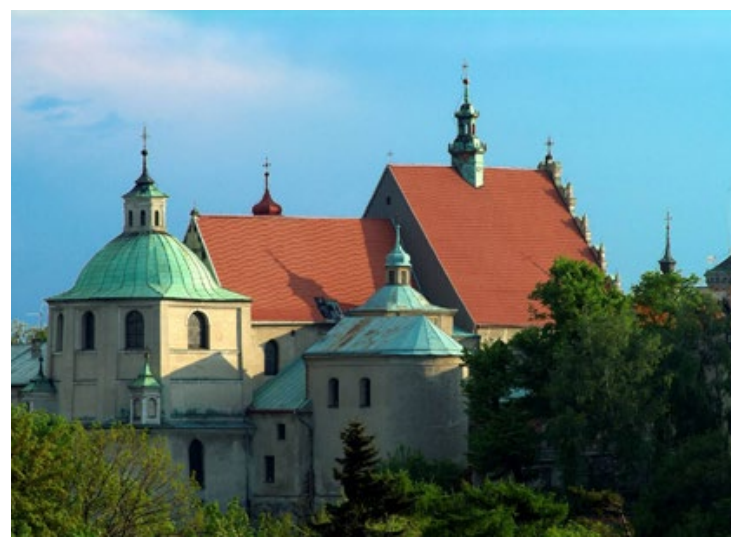

Ryc. 5. Klasztor o.o. dominikanów w Lublinie. Fot. Ze zbiorów WKZ Lublin.

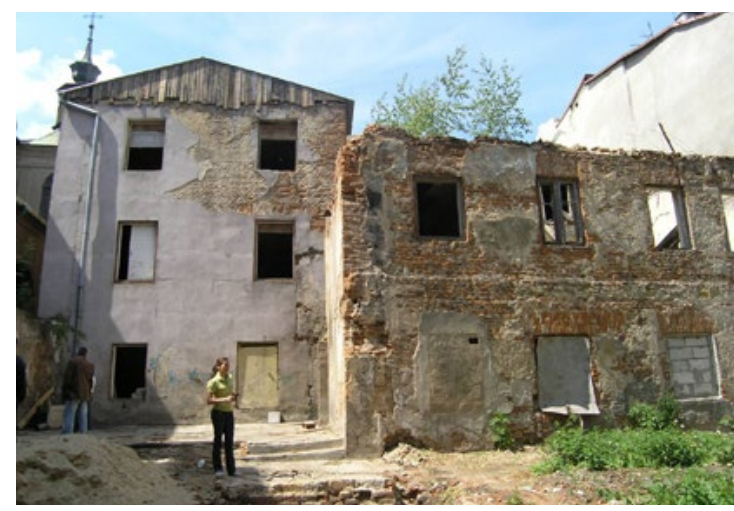

Ryc. 2. Zagrożona rozbiórką kamienica przy ul. Archidiakońskiej 1 w Lublinie. Fot. Ze zbiorów WKZ Lublin

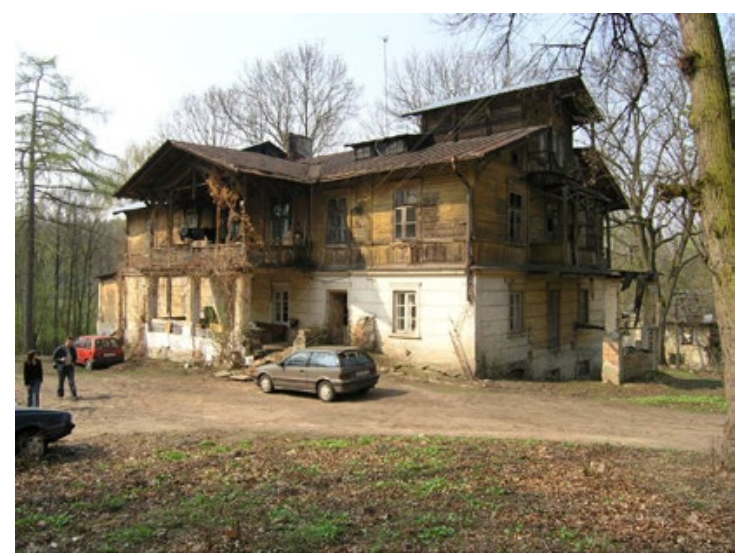

Ryc. 4. Dwór Górskiego w Nałęczowie, stan z 2007 roku. Fot. Ze zbiorów WKZ Lublin

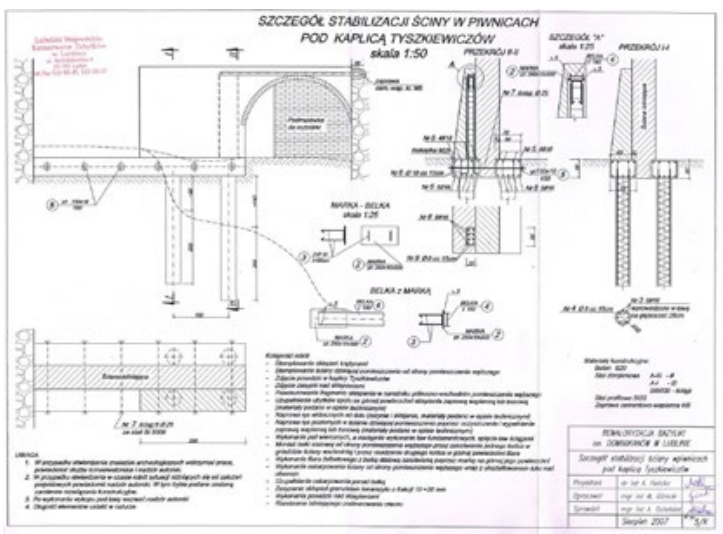

Ryc. 6. Rysunek projektu stabilizacji kaplicy Tyszkiewiczów z dokumentacji "Rewaloryzacja bazyliki o.o. dominikanów W Lublinie, proj. dr inż. A. Halicka, 2007 (proj. wykonawczy $\mathrm{z}$ archiwum WKZ) 
mu rozbiórka jeżeli nadal nie zostanie rozpoczęty remont kapitalny. Przykładem takiej sytuacji może być dawny budynek folwarczny wzniesiony na przełomie XVIII i XIX wieku i przebudowany na murowano-drewnianą letnią willę przez Michała Górskiego (jednego z założycieli uzdrowiska Nałęczów). Użytkowany współcześnie przez Muzeum Kazimierza Dolnego i Fundację Sanatoriów Kardiologicznych dla Rolników, został w roku 2001 zakupiony przez prywatną spółkę. Wykonane ekspertyzy konstrukcyjne wskazywały na konieczność pilnych robót remontowych. Przymuszany w toku kolejnych kontroli konserwatorskich i budowlanych właściciel wykonał do 2012 roku jedynie doraźne zabezpieczenia kondygnacji murowanej. Stan kondygnacji drewnianej z gankami i ozdobnymi werandami nadal się pogarszał. W 2013 roku wykonane zostały kolejne doraźne zabezpieczenia (podparcia stemplami, naprawa zadaszeń, demontaż i zabezpieczenie dekoracji snycerskiej). Docelowe prace remontowe wciąż nie zostały podjęte, a doraźne działania nie dają gwarancji przetrwania budynku.

Zdarzają się także rozbiórki samowolne. XIX w. dwór w Bełżcach, adaptowany po parcelacji majątku na szpital, był nieużytkowany w ostatnim dziesięcioleciu lecz doraźnie zabezpieczany. W roku 2012 został zakupiony przez prywatnego nabywcę, który rozpoczął remont. Według projektu i orzeczenia konstruktora mury konstrukcyjne miały być zachowane, a roboty budowlane zabezpieczające miały uwzględniać podbicie fundamentów. Jak się okazało w trakcie kontroli prace rozpoczęto jednak od rozbiórki dachu, stropów i wyburzania murów dworu. Rozbiórka była całkowicie niezgodna z wydanymi pozwoleniami. Roboty zostały wstrzymane przez konserwatora i organ budowlany, sprawa została skierowana do sądu, który nałożył karę grzywny. Nie zmienia to faktu, że remont zabytku został zastąpiony jego odbudową. Oryginalna struktura to dziś znikomy procent całości, co zapewne przesądzi o skreśleniu dworu z rejestru zabytku. Przy dzisiejszych możliwościach technicznych i materiałowych rozbiórka obiektu zabytkowego to z pewnością działanie wyjątkowe i ostateczne.

Omawiając problemy dotyczące awaryjnego stanu zabytków nie sposób pominąć nagłych zniszczeń losowych np. spowodowanych pożarami - w których to przypadkach najczęściej występuje znaczne zniszczenie struktury budynku i zagrożenie bezpieczeństwa. Jedyną drogą działań pozostaje w takim przypadku rekonstrukcja obiektu. Przykładem może być tu być drewniany kościół w Bezwoli, który spłonął tuż po zakończeniu prac konserwatorskich i został starannie odbudowany przez zdeterminowanych parafian. Inne dwa drewniane zabytki: dwór w Niezabitowie i drewniano-murowany dwór w Sobianowicach także uległy spaleniu lecz w obu przypadkach odbudowy dotychczas nie podjęto.

Zagrożenie bezpieczeństwa w związku z awaryjnym stanem konstrukcji wystąpiło także w kilku wyjątkowo wartościowych obiektach architektonicznych zabytkowego Lublina. Dzięki starannym analizom i badaniom ustalona została przyczyna uszkodzeń. W oparciu o przyjęte nietypowe rozwiązania zaprojektowane przez konstruktorów - praktyków wykonane zostały z powodzeniem prace ratownicze przy stabilizacji fundamentów XV w. Kaplicy Trójcy Świętej na zamku lubelskim, osuwających się w lessowym podłożu skarp wzgórza staromiejskiego Z kolei w przypadku fundamentów i murów XVII w. kaplicy Tyszkiewiczów w bazylice o.o. dominikanów, kamienno-ceglane ściany fundamentowe o grubości 1.1-1.5 m wzmocnione zostały za pomocą pali i dodatkowych żelbetowych ław fundamentowych zespolonych ściągami.

Wyzwaniem było też rozwiązanie problemu zabezpieczenia sklepienia nad skarbcem w Archikatedrze Lubelskiej. Stwierdzono, że osiadanie ściany zewnętrznej skarbca spowodowało postępujące rozspojenia i deformacje geometryczne eliptycznego sklepienia o spłaszczonej formie, pokrytego bogatą XVIII w. dekoracją malarską autorstwa Józefa Meyera. Uwarunkowania konserwatorskie nie pozwalały na typowe działania, stąd wykluczono możliwość zastosowania ściągu. Wzmocnienie wykonano w oparciu o wyniki badań konstrukcyjnych. W poziomie poddasza wprowadzono belkę stalową opartą na ściance kolankowej skarbca i murze katedry, z systemem cięgien stalowych mocowanych nakrętkami napinającymi. Belki zintegrowano $z$ istniejącymi krokwiami za pomocą blach, zabezpieczono dodatkowo pulpitowy dach skarbca.

Tak wykonane zabezpieczenia w niczym nie zakłóciły wnętrza unikatowego pomieszczenia i jego wystroju.

W przypadku awaryjnego stanu wieży zamkowej w Janowcu dyskusje nad sposobem jej ratowania toczyły się kilka miesięcy. Południowo-wschodnia część wieży wykazywała niebezpieczne oznaki nierównomiernego osiadania. Poparta orzeczeniem konstrukcyjnym początkowa propozycja rozbiórki, a następnie rekonstrukcji nie uzyskała akceptacji konserwatorskiej. Podjęto więc trud znalezienia doraźnego sposobu wzmocnienia struktury murów z zastosowaniem systemu naciągów. Po wielu analizach zdecydowano o wprowadzeniu mikropali iniekcyjnych z perforowanych rur wwierconych w grunt na głębokość $4 \mathrm{~m}$ i zagłębionych w litej skale na $1 \mathrm{~m}$.

Odcinkowo na obwodzie baszty założono żelbetowy oczep i zrekonstruowano licową warstwę muru z kamienia maskując wykonane wzmocnienia. 


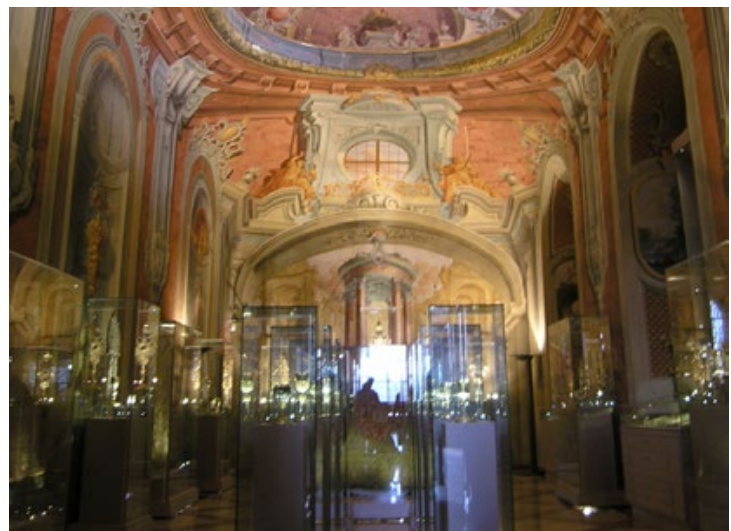

Ryc. 7. Skarbiec Archikatedry Lubelskiej z XVIII w. dekoracją malarską J. Meyera (fot. autora)

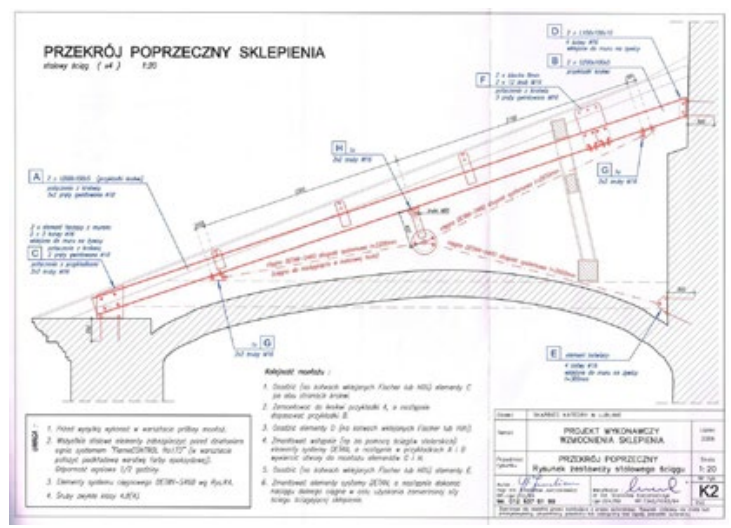

Ryc. 9. Rysunek projektu wzmocnienia sklepienia i więźby dachowej nad pom. Skarbca w z dokumentacji "Skarbiec w Katedrze Lubelskiej". proj. dr inż. S. Karczmarczyk, AC Konserwacja Zabytków, Kraków 2005-2006 (proj. wykonawczy z archiwum WKZ

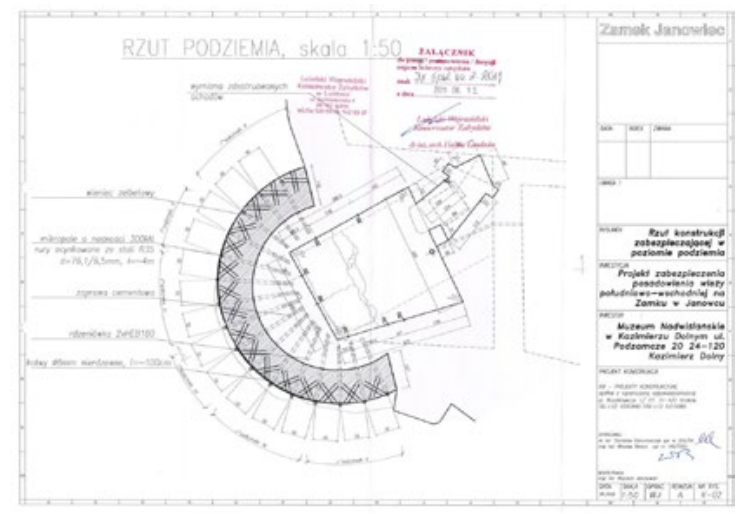

Ryc. 11. Rysunek projektu zabezpieczenia posadowienia wieży. Projekt budowlany aut. dr inż. S. Karczmarczyka, 2011 r. $\mathrm{z}$ archiwum WKZ Lublin

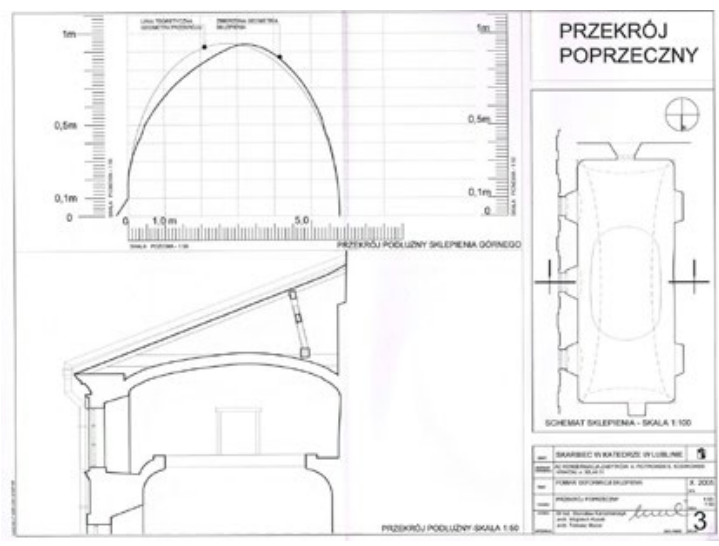

Ryc. 8. Rysunek analityczny z projektu zabezpieczenia sklepienia Skarbca

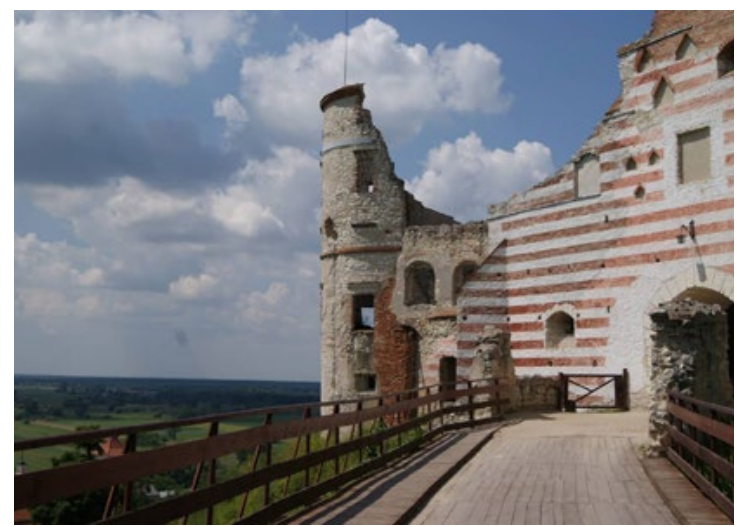

Ryc. 10. Wieża płd-wsch. w zespole zamkowym w Janowcu. Fot. zez zbiorów WKZ Lublin

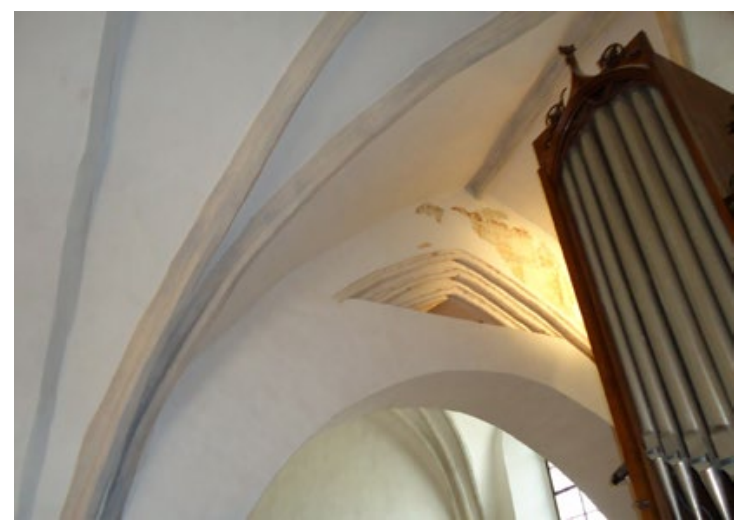

Ryc. 12. Łuk gotycki przesłonięty łukiem wzmacniającym w kościele pobrygidkowskim w Lublinie, Fot. autora 
W niektórych obiektach uwarunkowania konserwatorskie wskazują na zasadność uczytelnienia dawnej konstrukcji poprzez usunięcie wzmocnień konstrukcyjnych wprowadzonych wtórnie w zabytku.

Wówczas równie istotne jest orzeczenie konstruktora, który po dokonaniu oceny technicznej decyduje o możliwości zmian. Nie zawsze jest to decyzja pozytywna. Podczas prac badawczych w XV w. lubelskim kościele brygidek (obecnie wizytek) pod wezwaniem Matki Boskiej Zwycięskiej odkryty został gotycki fragment łuku arkady zdobionej dekoracją malarską.

Niestety w części był on przesłonięty wtórnym łukiem wprowadzonym przed laty w celu wzmocnienia konstrukcyjnego. Pomimo wniosku badaczy i konserwatora o usunięcie wtórnego elementu i pełne wyeksponowanie znaleziska w ocenie konstruktora demontaż łuku podpierającego nie był możliwy, gdyż zagrażałby stabilności konstrukcji. Pierwotny łuk gotycki widoczny pozostał więc tylko w możliwych do odsłonięcia fragmentach.

\section{Podsumowanie}

W postępowaniu konserwatorskim - zarówno w przypadku zamierzonej adaptacji, jak i w stanie zagrożenia czy awarii budowlanej - stan zabytku wymaga niezbędnej interwencji. Racje konstruktora i konserwatora są równie ważące, a rozważna ocena i analiza powinna wskazać możliwości rozwiązań. Zgodnie z zaleceniami dokumentu Recomendation for Analysys and Restoration of Historical Structures, przyjętego przez ICOMOS w 2003 r. konserwacja musi opierać się na znajomości historii, problemów konstrukcyjnych i koniecznych interwencji w zabytkową strukturę obiektu".

Wiedza i doświadczenie, priorytetowe traktowanie wartości zabytku pozwalają na spójne wypracowanie najlepszych decyzji. Jeden wspólny głos konstruktora i konserwatora pozwala na osiągnięcie nadrzędnego celu jakim jest bezpieczeństwo i utrwalenie zabytku.

\section{Piśmiennictwo}

[1] Z. Janowski, Ł. Hajdys, P. Krajewki, Analiza i naprawa historycznych sklepień w obiektach historycznych [w:] Materiały z XXIII konferencji naukowo-technicznej „Zapobieganie, diagnostyka, naprawy, rekonstrukcje”. Międzyzdroje 2007

[2] P. Kuleta, M. Pikos, G. Słowek, Problemy konstrukcyjne remontowanego budynku zabytkowego. Wiadomości Konserwatorskie $\mathrm{Nr}$ 26/2009

[3] R. Marcinkowski, M. Banach, Problem zapewnienia jakości robót remontowych w obiektach zabytkowych, [w:] Wybrane zagadnienia rewitalizacji obiektów zabytkowych, Politechnika Warszawska Filia w Płocku, Płock 2014

[4] T. Seruga, M. Płachecki, S. Seruga, Problemy konstrukcyjnego przystosowania obiektu przemysłowego do nowej funkcji, Budownictwo. Czasopismo Techniczne Politechniki Krakowskiej, wyd. PK 2-B/2009, zeszyt 9 rok 106

[5] Wartościowanie w ochronie zabytków, praca zbiorowa pod red. B. Szmygina, wyd. ICOMOS. PL, 2012

[6] Inżynieryjne problemy ochrony staromiejskich zespołów zabytkowych, Konferencja Naukowo-Techniczna "REW-INŻ." Wyd. Kraków 2005-2009

[7] Materiały z 2 Konferencji REGENTIF: Rewitalizacja miast poprzez regenerację terenów poprzemysłowych: innowacja i dobra praktyka, Politechnika Krakowska, Kraków 2007 


\section{Constructure and conservation problems at old monuments of architecture - selected examples}

Abstract: The process of adaptation old listed buildings requires participation and cooperation the specialists in conservation, constrution and architecture sience. The main goal is to recognice the history and old structure to protect most value parts of the building. Only this knowledge suppotred deep experience of experts can guarantee suitable decisions about sphere of interference with the monument and its safety. The scale of problems we can view in examples from Lublin and Lubelszczyzna region.

Key words: adaptation, preservation, conservation of old monuments 